\title{
Do Inflation Targeters Outperform Non-targeters?
}

\author{
Michael J. Dueker and Andreas M. Fischer
}

\begin{abstract}
Ten years of empirical studies of inflation targeting have not uncovered clear evidence that monetary policy that incorporates formal targets imparts better inflation performance. The authors survey the literature and find that the "no difference" verdict concerning inflation targeting has been robust to a wide range of countries and methods of analysis, starting with a study by Dueker and Fischer (1996a). The authors present updated Markov-switching estimates from the original Dueker and Fischer (1996a) article and show that their early conclusions about inflation targeting among early adopters have not been overturned with an additional decade of data. These findings to date do not rule out the possibility, however, that formal inflation targets could prove pivotal if the global environment of disinflation were to reverse course. (JEL E52, E42, E61)
\end{abstract}

Federal Reserve Bank of St. Louis Review, September/October 2006, 88(5), pp. 431-50.

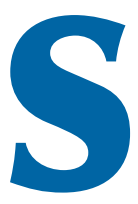

ince its inception in the early 1990s, inflation targeting has unleashed considerable debate on the merits of the new policy framework. Its introduction has raised numerous issues: the difficulty of evaluating central bank performance in achieving the target, the effect of inflation targeting on inflation expectations, the choice of inflation indicators, links with exchange rate policy, and the interaction between the central bank and the central government. Analysis of these issues was valuable not only to decisionmakers and analysts in the countries where inflation targets were already in use, but also to those countries contemplating such a policy. Revisiting the perceived merits of inflation targeting is especially timely now that Ben Bernanke, who has a clear academic record in favor of a quantitative inflation objective, is the Chairman of the Board of Governors of the Federal Reserve System.

Contributions to the policy debate concerning inflation targeting have come in the form of theoretical analysis and empirical evidence. This note updates the empirical evidence from an early study on inflation targeting by Dueker and Fischer (1996a) (denoted as D-F hereafter) that sought to provide an answer to the question: Do inflation targets impart an aversion to inflation and inflation variability among inflation-targeting countries above and beyond that displayed by non-inflationtargeting countries? D-F examined this question by matching three early adopters of inflation targets-New Zealand (which adopted an inflation target in 1990), Canada (1991), and the United Kingdom (1992)—with three neighboring countries that did not have formal inflation targets in the early 1990s-Australia, the United States, and Germany, respectively. All three inflation targeters achieved their announced targets ahead of schedule, perhaps in part because the 1990s saw a marked disinflation throughout the industrialized world.

Numerous studies have re-examined the empirical effects of inflation targeting. Many subsequent studies have followed the formula laid out in D-F: Match each inflation-targeting

Michael J. Dueker is an assistant vice president and economist at the Federal Reserve Bank of St. Louis, and Andreas M. Fischer is a research adviser at the Swiss National Bank. Andrew Alberts provided research assistance.

(C) 2006, The Federal Reserve Bank of St. Louis. Articles may be reprinted, reproduced, published, distributed, displayed, and transmitted in their entirety if copyright notice, author name(s), and full citation are included. Abstracts, synopses, and other derivative works may be made only with prior written permission of the Federal Reserve Bank of St. Louis. 
country with a neighboring non-inflation-targeting country and look for differences in their respective inflation outcomes. Despite permutations of the empirical technique, the introduction of real factors, longer historical time series, and a greater number of countries to study, the initial finding has not been overturned. In fact, we show that the basic findings from D-F regarding the timing of the downward shifts in the policy-implied baseline rate of inflation are quite robust to an extension of the sample from 1995 to 2005. For this reason, we argue that, although inflation targeting enjoys considerable academic sympathy and the endorsement of many international organizations, there remains little empirical evidence that an inflation-targeting regime performs better than a non-inflation-targeting regime in the same circumstances.

\section{SOME PROBLEMS WITH COMPARING TARGETERS WITH NON-TARGETERS}

Before reviewing the subsequent literature, it is important to understand some of the limitations of the empirical literature that tries to document the macroeconomic effects of inflation targeting. One issue is that, even if a central bank is recognized as an inflation targeter, the dating of the new policy regime is often contentious. The fact that the adoption date is arguable says something indirectly about the clarity of a central bank's program. For example, Bernanke et al. (1999) and Ball and Sheridan (2004) set Australia's adoption date at 1994:Q1, whereas Rasche and Williams (2005) document an earlier Reserve Bank of Australia announcement from June $1993 .{ }^{1}$ Similarly, Sweden and South Africa have presumptive adoption dates that differ from the date of the first announced inflation target. Does this mean that some inflation targeters were targeting inflation up to two years before the announcement of official targets? Getting the date right is important because many studies are interested in the effect

1 Siklos (1999) sets the date at January 1993 and Johnson (2003) at March 1993. See also footnote 9 of Almeida and Goodhart (1998). that the announcement of inflation targeting has on financial markets and inflation expectations. If an announcement of an inflation program is credible, the strongest evidence of its effect on expectations and financial market variables will be in the first months after the declaration. Apart from Vega and Winkelried (2005), there is little work on the robustness of findings to alternative adoption dates. Some studies, such as Ball and Sheridan (2004), Hyvonen (2004), Batini and Laxton (2005), and Levin, Natalucci, and Piger (2004), assume a uniform adoption date across countries.

An issue that the D-F study raises that still has not been resolved in the discussion of central bank preferences and inflation targets is endogeneity. Numerous studies argue that inflation targets are a commitment device and the establishment of a target accounts for the observed change in the central bank's policy rule. An alternative interpretation is that central bankers, regardless of whether they are inflation targeters or not, have grown to take inflation much more seriously today than in the past and that the announcement of an inflation target simply affirms this evolution. The endogeneity criticism was first mentioned by Alders et al. (1996) and repeated later by Uhlig (2004) and Gertler (2005) in published commentaries.

An inherent weakness of the side-by-side comparisons of inflation targeters and noninflation targeters is that conclusions are based on point estimates. No study provides confidence bands to test whether one central bank moved significantly sooner or reduced inflation significantly more than another. Against this background, quantifying the success of inflation targeting using a scorecard approach based on low mean inflation, low inflation variability, and low inflation persistence becomes more difficult when the empirical sample coincides with a global disinflation.

Attempts to remove common trends and common cycles between targeters and non-targeters are not undertaken. ${ }^{2}$ What arises is a beauty contest,

\footnotetext{
2 An exception is Lee (1999). He uses a data decomposition procedure, which involves cointegration and canonical correlation analysis, to remove common trend and cyclical components from the data used in D-F.
} 
where the performance measures are interpreted subjectively. One issue concerns the use of a control group of non-inflation targeters. Studies by D-F and Groeneveld, Koedijk, and Kool (1998) use neighboring countries in their bilateral framework to control for regional shocks. Almeida and Goodhart (1998), Nadal-DeSimone (2001), Siklos (1999), and Rasche and Williams (2005) instead focus on successful non-inflation targeters (i.e., the Federal Reserve, Bundesbank, or the Swiss National Bank) in their comparisons. More recent studies by Cecchetti and Ehrmann (2002) and Vega and Winkelried (2005) expand the set of noninflation targeters but at the expense of lowering the performance requirement of the non-inflation targeters.

A further problem in interpreting the results lies in the classifications of the inflation targeters. There is little dispute that the initial targeters such as New Zealand, Canada, Sweden, and the United Kingdom qualify as inflation targeters. The inclusion, however, of de facto and not only de jure inflation targeters raises questions. Finland, Greece, and Spain are cases in point. It is unclear how the Exchange Rate Mechanism and other considerations related to their entry to the European Monetary Union allowed their central banks to act as independent inflation targeters. In some cases, it is not clear whether a country, such as Switzerland, is a de facto inflation targeter. The Swiss National Bank-a self-declared nontargeter-appears in many studies as a de facto inflation targeter after 2000, yet the European Central Bank (ECB) does not. Although both of these central banks produce inflation forecasts and operate with the same definition of price stability, the ECB is not classified as an inflation targeter because of its twin-pillar strategy, which targets the stock of money and the inflation rate. ${ }^{3}$

The comparative literature on inflation targeting has been extended to emerging markets. This evidence tends to be more favorable than for industrialized countries. The merits of inflation targeting in emerging countries are not easily compared with those in industrialized countries.

3 See Batini and Laxton (2005) and the International Monetary Fund (2005) for a discussion on this issue.
Mishkin (2004) highlights issues of preconditions, a later adoption date, and the frequent use of a declared exchange rate objective. For these reasons the studies focusing on emerging markets are not discussed here. Contributions in this area include Batini and Laxton (2005), Fraga, Goldfajn, and Minella (2004), the International Monetary Fund (2005), Dueker and Fischer (2001), and Jonas and Mishkin (2005).

\section{TARGETERS VERSUS NON-TARGETERS: THE EMPIRICAL EVIDENCE}

Empirical studies on the merits of inflation targeting document evidence from survey data, output volatility, inflation persistence, and changes in central bank reaction functions. We summarize this evidence below. What emerges is a mixed picture at best. Although different measures register an improvement in inflation performance in the targeting countries, it is difficult to find evidence that shows inflation-targeting regimes perform better than neighboring noninflation-targeting regimes.

\section{Survey Expectations}

In evaluating inflation targeters, a highly relevant consideration is whether the expectations of market participants concerning inflation rates have fallen together with recent actual rates. Survey expectations have been used frequently as a proxy for inflation expectations. ${ }^{4}$ Laidler and Robson (1993) and three different studies in a volume edited by Leiderman and Svensson (1995)—Fischer (1995), Svensson (1995), and Bowen (1995)—found that survey measures of expected inflation still lagged actual inflation in Canada, New Zealand, Sweden, and the United Kingdom after the introduction of inflation targets. Bernanke et al. (1999) compare actual inflation with average survey predictions of inflation made

\footnotetext{
4 Other studies such as Groenevald et al. (1998) focus on interest rate and inflation forecasts before and after the introduction of inflation targets. Their results for the same six countries used in $\mathrm{D}-\mathrm{F}$ suggest that inflation targets have not enhanced the credibility of the targeters.
} 


\section{Dueker and Fischer}

6 months, 12 months, and 18 months earlier. They find for New Zealand, Canada, the United Kingdom, and Sweden that the adjustment was for the most part gradual. Johnson (2003) extends the analysis to include Australia and conditions on the announcement of inflation targets. $\mathrm{He}$ finds that in Australia and Canada inflation targets reduced expected inflation slowly; in New Zealand and Sweden there was an immediate drop; in the United Kingdom no effect is seen.

Survey evidence has been criticized by McCallum (1998) and others in that they exhibit various weaknesses including non-homogeneity across countries and time as well as the inherently dubious nature of unofficial survey data. Johnson (2002) addresses these concerns by pooling a panel of five targeting countries with six non-targeting countries. His unified framework works with a homogenous survey, is able to control for measurement problems, and offers a direct test between targeters and non-targeters. He finds that neither the variability of expected inflation nor the average absolute forecast error falls after the announcement of targets when one controls for the level and variability of past inflation.

\section{Output Volatility}

Cecchetti and Ehrmann (2002) ask whether inflation targeting increases output volatility; they seek to measure the impact of inflation targeting on output and inflation for a set of 23 countries, including 9 that target inflation explicitly. The hypothesis is that aggregate shocks that move output and inflation in opposite directions create a trade-off between output and inflation variability. ${ }^{5}$ Assuming that the central bank's objective can be written as a simple quadratic loss function, Cecchetti and Ehrmann (2002) estimate the realized output and inflation patterns of 23 industrial and developing economies to infer the degree of policymakers' inflation variability aversion. Their evidence allows them to conclude that both inflation-targeting and non-inflation-targeting

\footnotetext{
5 Several studies focus on sacrifice ratios. Again the record is mixed. Almeida and Goodhart (1998) show that the sacrifice ratios increased in the 1990s for the inflation targeters, whereas Corbo et al. (2002) find that the average sacrifice ratio for targeters was lower than for non-targeters in the 1990s.
}

European countries increased their revealed aversions to inflation variability during the preEuropean Monetary Union period and experienced accompanying increases in output variability.

\section{Inflation Persistence}

It is well known that inflation dynamics are heavily influenced by regime changes in monetary policy. A frequently noted example is that the level of inflation persistence was lower during the gold standard. When considering whether inflation targeting represents a fundamental change in monetary policy, a question arises: Did inflation targeting reduce the level of persistence in inflation? The evidence finds that there is a significant drop in inflation persistence across countries in the 1990s. Once again, however, the importance of inflation targets as a determinant of inflation persistence is mixed when one compares the records of targeters and non-targeters.

Although D-F do not focus explicitly on inflation persistence in their study, the estimates of the transition probabilities of the two-state Markov process for the baseline inflation path (i.e., implicit inflation target) allow one to make inferences about inflation's persistence. Their results show that for both targeters and non-targeters there is a high level of persistence in the low- and highinflation state. The estimates of the transition probabilities are above 0.95 in most countries, and no evidence of a difference in behavior between the two sets of countries is apparent. This evidence from the transition probabilities lends further support to the claim in D-F that there is no substantive difference between targeters and non-targeters.

Univariate regressions of inflation are another way to test for the impact of inflation targeting on inflation persistence. Siklos (1999) provides point estimates from an AR(1) model for samples that roll at two-year intervals since 1968. His evidence shows that persistence has been lowest for the United States and that the drop in persistence in the targeting countries follows that of the United States. Pétursson (2004) and Vega and Winkelried (2005) use an expanded set of targeters and confirm Siklos's (1999) inconclusive findings based on persistence measures. 
An alternative approach to measure whether inflation persistence has fallen is to compute impulse responses. Ball and Sheridan (2004) compute impulse responses showing the effects of inflation shocks on future inflation. The results for CPI inflation show that inflation persistence has decreased over time. The estimates by Ball and Sheridan (2004) find that in the pre-targeting periods, a unit inflation shock in quarter $t$ raises inflation at $t+1$ by more than 0.4 percentage points and this effect dissipates slowly. For the targeting period, the effect is around 0.2 at $t+1$ and disappears in three quarters. Because this pattern holds for both control groups, this result is interpreted as evidence that targeting does not much affect inflation behavior.

\section{"NO DIFFERENCE" THROUGH A DECADE OF STUDIES}

A common explanation for the "no difference" result is that inflation targeting represents a convergence to best practices in the conduct of monetary policy. Bernanke et al. (1999) and Mishkin (2002) suggest that the successful non-inflation targeters' strategies for conducting monetary policy have many of the same characteristics as those pursued by inflation targeters. ${ }^{6}$ Both groups focus on the long-run goal of price stability and stress transparency, accountability, and flexibilitythe key elements of inflation-targeting regimes. In a nutshell, inflation targeting is best regarded as a framework for the conduct of monetary policy and not as a monetary policy rule. Such an interpretation allays the criticism that econometric estimates ought to find something unique about the policy rules of inflation targeters.

The "no difference" verdict also needs to be qualified in two ways. First, no empirical study provides an argument against inflation targeting or shows that it is harmful. Ball and Sheridan (2004) suggest that inflation targeting may be desirable for political rather than economic reasons. ${ }^{7}$ These benefits are not easily measured.

\footnotetext{
${ }^{6}$ Bernanke et al. (1999) emphasize the role of transparency and its consistency with the principles of a democratic society.

7 Ball and Sheridan (2004) argue that it is an open question whether
}

Second, inflation targeting may improve economic performance in the future. The economic environment has been quiet during the past decade, and thus the true test awaits. No one really knows what would happen to small inflation-targeting countries if inflation were to reawaken in one of the big three (i.e., the United States, the euro area, or Japan).

\section{UPDATED RESULTS FOR THREE COUNTRY PAIRS FROM DUEKER AND FISCHER}

$\mathrm{D}-\mathrm{F}^{8}$ looked for evidence of a significant change in a central bank's reaction function after the introduction of inflation targeting as evidence of an increase in the bank's aversion to inflation. Here we present updated estimates from their empirical model to check whether the conclusions, which were based on short spans of inflation targeting, would have differed from a retrospective vantage point. D-F used a monetary policy reaction function that targets inflation in an open economy while allowing for occasional feedback from the gap between the exchange rate and its implicit target. (See McCallum, 1987.) Note that this is a model of inflation targeting and not exchange rate pegging, however. The feedback from the exchange rate is analogous to a monetary response to an output gap. Like the output gap, the exchange rate gap is specified such that it will close eventually regardless of monetary policy. Any monetary policy response to the exchange rate is intended only to attenuate the gap and its consequences. The true nominal target is the inflation rate. We also present results for the case where

the improvement in the inflation performance of inflation targeting countries in the 1990s is largely a function of monetary policy or of "regression to the mean," but lean toward the latter view. Hyvonen (2004) shows historical and regional evidence that is inconsistent with the "regression to the mean" view.

8 The original paper by Dueker and Fischer (1996a) was first presented in a CEPR workshop titled "Inflation Targets" held in Milan in November 1994 and later at a conference titled "Monetary Policy in a Converging Europe" organized by the De Nederlandsche Bank $\mathrm{NV}$ and the Limburg Institute of Financial Economics of the University of Limburg in February 1995. The papers and proceedings of the latter conference were published the following year by Kluwer Academic Publishers. 


\section{Dueker and Fischer}

monetary policy is assumed not to respond to the exchange rate at all, and the conclusions about the shifts in trend inflation are quite robust to this alternative specification.

Neumann and von Hagen (2002) and Corbo, Landerretche, and Schmidt-Hebbel (2002) perform a similar cross-country comparison using a Taylor rule. Both studies show that the weight on the inflation gap increases after inflation targeting was introduced. As mentioned in Mishkin (2002), however, the evidence also says that the central banks are not doing their job because the long-run inflation coefficient remains less than unity. Mishkin (2002) concludes that the Taylor rule estimates do not allow one to conclude that inflation-targeting countries have improved monetary policy enough to achieve price stability. We choose to use an inflation-targeting model where, if the forecasted relation between the interest rate instrument and inflation holds, then inflation will be at its target level every period. In a Taylor rule, in contrast, the inflation target is only a long-run target. To show that the target is not binding in the short run, we note that in his original study Taylor (1993) fit the interest rate well between 1987 and 1993 using a 2 percent longrun inflation target, even though the average rate of consumer price inflation was actually twice as high-4.0 percent-during the same period.

Thus, a Taylor rule lacks a timetable for reaching the target, a feature that is important to inflation targeting in practice.

\section{DESCRIPTION OF THE EMPIRICAL MODEL}

The central bank reaction function we estimate is closely related to a Taylor rule, but it has a concrete objective to achieve a (time-varying) target rate of inflation in the next period. The time-varying inflation target recognizes that it is not realistic to expect that the inflation rate will jump to a long-run desired level below 2 percent next period if it recently has been running at more than 4 percent. Our reaction function is an instrument-target relationship (ITR) rule that takes a near-term target or "baseline" inflation rate and uses a minimum-mean-squared-error (MMSE) forecast of the relationship between the policy instrument and inflation to derive an implied quarterly change in the 3-month T-bill interest rate instrument, $i$. The MMSE forecast trades off bias and forecast error variance and takes into account covariances between components. Thus, unlike the mathematical expectation, the MMSE forecast is not a linear operator and cannot be passed across linear components of the function being forecast. If the near-term target or "baseline" inflation rate is denoted $\pi_{0 t}$ where $\pi$ is inflation and $\alpha$ is given, then a stripped-down version of our policy rule is

$$
\Delta i_{t}=[\Delta i+\alpha \pi]_{M M S E(t \mid t-1)}-\alpha \pi_{0 t},
$$

where $[\Delta i+\alpha \pi]_{M M S E(t \mid t-1)}$ is the MMSE one-stepahead forecast. This forecast links the change in the interest rate to the desired near-term inflation rate. We can show that our rule is closely related to the following inflation forecast Taylor rule with interest rate smoothing:

$$
i_{t}=\rho i_{t-1}+(1-\rho) i^{e}+\alpha\left(\pi_{t \mid t-1}-\pi_{0 t}\right),
$$

where $i^{e}$ is the long-run equilibrium short-term nominal interest rate, equal to the inflation target plus the equilibrium real rate of interest, and $\pi_{t \mid t-1}$ is the forecasted rate of inflation. Equation (2) satisfies the Taylor principle provided that $\rho+\alpha \geq 1$. Note that we have omitted feedback from the output gap from the Taylor rule in equation (2) in order to focus on the core relation between equations (1) and (2) as models of inflation targeting.

The forecast-based rule of equation (1) and the Taylor rule of equation (2) are equivalent up to an approximation:

$$
\text { (3) }[\Delta i+\alpha \pi]_{M M S E(t \mid t-1)} \approx(1-\rho)\left(i^{e}-i_{t-1}\right)+\alpha \pi_{t \mid t-1} \text {. }
$$

Examination of equation (3) shows that the correspondence between the two rules is quite close: When inflation is near the target level, $(1-\rho)\left(i^{e}-i_{t-1}\right)$ is a reasonable "forecast" of next period's change in the interest rate whereby the interest rate is expected to return gradually to its long-run mean.

Despite the similarities, the inflation-targeting rule has some advantages relative to the Taylor 
rule. First, it does not assume that policymakers know the long-run equilibrium real rate of interest. Second, it does not depend on a stand-alone inflation forecast. Indeed, a controversial feature of the inflation forecast Taylor rule is the interest rate assumption that goes into the inflation forecast. The Bank of England, for example, assumes in its inflation report that the interest rate instrument will remain constant at its current level, although critics of this approach note that often the need for further interest rate hikes or cuts is obvious. Equation (1), in contrast, is based on a forecast of the relation between inflation and the interest rate instrument, so no stand-alone inflation forecast appears. The ITR rule's forecast allows policy to aim at a specific near-term inflation target in the next period, as inflation-targeting countries might do in practice.

The full empirical model from D-F does not attribute all fluctuations in period-by-period intended inflation to changes in the baseline inflation target because the inflation target is assumed to be subject to Markov switching such that $\pi_{0 t}$ is a probability-weighted average of a high and low rate. A second source of fluctuation in intended inflation comes from a desire to push next period's inflation above or below the trend rate to respond to exchange rate considerations. D-F specifically made a modeling choice to leave out a policy response to the output gap. This avoids the use of variables that are subject to data revisions. This way, filtered quantities from the model represent pieces of information that would have been available to policymakers in real time. The data included in the analysis were interest rates, exchange rates, and consumer prices. Realtime data sets for output and monetary aggregates for all six countries are not available as far back as the 1970s. Moreover, recent results on optimal policy rules have shown that the response to output has very small or zero weight in optimal rules; see Svensson and Woodford (2004) and Woodford (2004).

The following equations incorporate these two potential motives for modifying short-run intended inflation. Several parameters are assumed to be subject to discrete changes because, for example, the central bank chooses to respond only episodically, if at all, to the exchange rate. We know that some of the central banks in our sample, such as Canada and New Zealand, have published monetary conditions indices that weigh interest rate and exchange rate movements in tandem to gauge the stance of monetary policy. In this case, it is natural to conclude that exchange rate movements at times have influenced the central bank's judgment regarding the appropriate interest rate. Even though the Reserve Bank of Australia declines to publish a monetary conditions index, the Deputy Governor, Glenn Stevens, has said, "I am certainly not saying that we ignore the exchange rate, far from it....Policy makers must, and do, form views of the exchange rate as part of the policy process" (Stevens, 1998). For Germany, on the other hand, there was concern in 1978 about a sharp appreciation of the Deutsche mark and in the opposite direction in 1984-85. Great Britain pegged its exchange rate during its relatively brief entry in the European Monetary System from 1990 to 1992. Even before that, however, Britain pursued a managed float in the late 1980s that shadowed the Deutsche mark (Zurlinden, 1993). Nevertheless, we leave the importance of the exchange rate as an empirical issue, and we also present results where this channel of policy response is shut down, which yields similar conclusions about the similarity of inflation behavior across targeters and non-targeters. The exception is the United States. We never use a specification that allows for exchange rate feedback for the United States. Instead, we allow for feedback from the term spread between the 3-month T-bill rate and the 10-year Treasury bond rate because of the term spread's record as a forward-looking cyclical indicator.

In the D-F model, the trend rate of inflation can vary across time, especially between the pretarget era and the post-target era. In equations (4) through (8), ê is the baseline exchange rate conditional on the values of the Markov state variables and $\tilde{e}$ is the baseline rate not conditional on the values of the state variables. We allow for three state variables subject to Markov switching: $S 1$ for parameters related to the implicit inflation objective, $S 2$ for parameters related to exchangerate responses (the term spread for the United 


\section{Dueker and Fischer}

States), and $S 3$ for switching in the variance. In equations (7) and (8), $Y_{t}$ denotes available information through time $t$. To implement equation (1) as a model of policy, we set $\alpha=0.25$ and $\pi_{0 t}$ is allowed to depend on an unobserved two-state Markov process. This value of $\alpha$ makes sense if a 25-basis-point drop is the response of inflation next period to an interest rate hike of 100 basis points. Other values of $\alpha$ might lead to a better policy rule, but we needed to make a choice to calculate MMSE forecasts for equation (1).

Interest rate changes:

$$
\begin{aligned}
\Delta i_{t} & =[\Delta i+0.25 \pi]_{t \mid t-1}-0.25 \pi_{0}\left(S 1_{t}\right) \\
& +\lambda\left(S 2_{t}\right)[\ln \tilde{e}-\ln e]_{t-1}+u_{t} \\
& \operatorname{var}\left[u_{t}\right]=\sigma^{2}\left(S 3_{t}\right) .
\end{aligned}
$$

Time-varying parameter forecast equation:

$$
\begin{aligned}
& {[\Delta i+0.25 \pi]_{t}=} \\
& \beta_{0 t}+\beta_{1 t} \Delta \ln e_{t-1}+\beta_{2 t} \pi_{t-1}+\beta_{3 t} \Delta i_{t-1}+v_{t}, \\
& \beta_{t}=\beta_{t-1}+v_{t} \\
& v_{t} \sim \operatorname{Normal}(0, Q) .
\end{aligned}
$$

Baseline exchange rate:

$$
\ln \hat{e}\left(S 2_{t}\right)=\delta\left(S 2_{t}\right) \ln \tilde{e}_{t-1}+\left(1-\delta\left(S 2_{t}\right)\right) \ln e_{t-1} .
$$

Expected baseline:

$$
\ln \tilde{e}_{t}=\sum_{j=0}^{1} \operatorname{Prob}\left(S 2_{t}=j \mid Y_{t}\right) \ln \hat{e}\left(S 2_{t}=j\right)
$$

$$
\begin{aligned}
& \operatorname{Prob}\left(S 1_{t}=i, S 2_{t}=j, S 3_{t}=k \mid Y_{t-1}\right)= \\
& \operatorname{Prob}\left(S 1_{t}=i \mid Y_{t-1}\right) \operatorname{Prob}\left(S 2_{t}=j \mid Y_{t-1}\right) \operatorname{Prob}\left(S 3_{t}=k \mid Y_{t-1}\right) \\
& P\left(S 1_{t}=1 \mid S 1_{t-1}=1\right)=p_{1} \\
& P\left(S 1_{t}=0 \mid S 1_{t-1}=0\right)=q_{1} \\
& P\left(S 2_{t}=1 \mid S 2_{t-1}=1\right)=p_{2} \\
& P\left(S 2_{t}=0 \mid S 2_{t-1}=0\right)=q_{2} \\
& P\left(S 3_{t}=1 \mid S 3_{t-1}=1\right)=p_{3} \\
& P\left(S 1_{t}=0 \mid S_{t-1}=0\right)=q_{3} .
\end{aligned}
$$

An important feature of the indicator model is the forecast for $[\Delta i+0.25 \pi]_{t \mid t-1}$. The forecasts are generated from a time-varying parameter model that is estimated by means of the Kalman filter, as in Dueker and Fischer (1996b). The Kalman filter generates MMSE forecasts. The randomwalk assumption regarding the $\beta$ coefficients suggests that agents need new information (other than the passage of time) to change their views about the relationships between variables. Equation (4) implies that intended inflation (interest rate changes minus the forecasted change in $\left.[\Delta i+0.25 \pi]_{t \mid t-1}\right)$ in any given quarter equals the baseline inflation path

$$
\begin{aligned}
& \pi_{0 t} \operatorname{Prob}\left(S 1_{t}=0 \mid Y_{t-1}\right) \pi_{0}\left(S 1_{t}=0\right) \\
& +\operatorname{Prob}\left(S 1_{t}=1 \mid Y_{t-1}\right) \pi_{0}\left(S 1_{t}=1\right)
\end{aligned}
$$

plus possible adjustments prompted by the gap between the actual and baseline exchange rates.

The size of the feedback coefficient, $\lambda\left(S 2_{t}\right)$, determines the rate at which one tries to close the exchange rate gap through policy actions. A low feedback coefficient implies that the central bank prefers gradualism as opposed to rapid adjustment and return to the target path. Such rebasing of the targets occurs for values of $\delta<1$. Consequently, shifts in the implicit model-implied target exchange rate are gradually accommodated. As $\delta$ decreases from 1 , the rate of accommodation increases. McCallum (1993) has used a similar weighting scheme; however, in his model $\delta$ remains constant.

Because of the autoregressive nature of equation (6), inferences of the state at time $t$ would depend on the entire history of past realizations of the state variables if it were not for the collapsing procedure of equation (7). An independence assumption in equation (8) for the three state variables reduces the number of parameters needed for the transition probabilities. Maximum-likelihood estimates of the parameters are obtained by maximizing the log of the expected likelihood, as in Hamilton (1988):

$$
\sum_{t=1}^{T} \ln \left(\sum_{i=0}^{1} \sum_{j=0}^{1} \sum_{k=0}^{1} \operatorname{Prob}\left(S 1_{t}=i, S 2_{t}=j, S 3_{t}=k \mid Y_{t-1}\right) L_{t}^{i, j, k}\right),
$$




\section{Table 1}

\section{Parameter Estimates with Occasional Exchange Rate Feedback}

\begin{tabular}{lllllll} 
Parameter & New Zealand & Australia & Canada & United States & United Kingdom & Germany \\
\hline$\pi_{0}(S 1=0)$ & $15.653(0.311)$ & $6.628(0.605)$ & $7.729(0.648)$ & $5.202(0.311)$ & $15.170(1.245)$ & $4.786(0.256)$ \\
$\pi_{0}(S 1=1)$ & $2.994(0.116)$ & $1.389(0.313)$ & $2.589(0.341)$ & $2.220(0.154)$ & $2.838(0.195)$ & $1.697(0.212)$ \\
$\lambda(S 2=0)$ & 0.000 & 0.000 & 0.000 & $0.059(0.035)$ & $0.016(0.013)$ & $0.011(0.003)$ \\
$\lambda(S 2=1)$ & $0.079(0.008)$ & $0.168(0.039)$ & 0.000 & $0.930(0.133)$ & $0.016(0.212)$ & $0.043(0.009)$ \\
$\delta(S 2=0)$ & 0.507 & $0.748(0.105)$ & 0.376 & $3.508(1.087)$ & $0.000(0.011)$ & 0.999 \\
$\delta(S 2=1)$ & $0.000(0.002)$ & $0.414(0.184)$ & $0.002(0.073)$ & $0.065(0.014)$ & $0.002(0.473)$ & $0.000(0.013)$ \\
$\sigma(S 3=0)$ & $2.042(0.342)$ & $2.746(0.561)$ & $3.737(1.098)$ & 0.000 & $2.127(0.389)$ & $3.206(0.990)$ \\
$\sigma(S 3=1)$ & $0.012(0.004)$ & $0.208(0.043)$ & $0.287(0.063)$ & 0.000 & $0.115(0.023)$ & $0.102(0.022)$ \\
$p_{1}$ & $0.978(0.016)$ & $0.990(0.012)$ & $0.830(0.095)$ & 0.920 & $0.987(0.012)$ & $0.930(0.054)$ \\
$q_{1}$ & $0.875(0.078)$ & $0.991(0.011)$ & $0.935(0.038)$ & $0.970(0.019)$ & 0.998 & $0.982(0.016)$ \\
$p_{2}$ & $0.934(0.067)$ & $0.963(0.030)$ & $0.995(0.321)$ & $0.990(0.011)$ & 0.996 & $0.967(0.018)$ \\
$q_{2}$ & $0.564(0.247)$ & $0.857(0.109)$ & $0.391(0.404)$ & $0.975(0.030)$ & 0.277 & $0.655(0.160)$ \\
$p_{3}$ & $0.874(0.064)$ & $0.974(0.020)$ & $0.942(0.039)$ & $0.664(0.132)$ & $0.906(0.062)$ & $0.955(0.036)$ \\
$q_{3}$ & $0.962(0.023)$ & $0.966(0.027)$ & $0.975(0.019)$ & $0.867(0.049)$ & $0.957(0.024)$ & $0.943(0.041)$ \\
Log-likelihood $)$ & -197.515 & -173.672 & -196.360 & -128.232 & -186.562 & -104.386 \\
Sample & $1975: \mathrm{Q} 1-$ & $1976: \mathrm{Q} 1-$ & $1970: \mathrm{Q} 1-$ & $1972: \mathrm{Q} 1-$ & $1972: \mathrm{Q} 1-$ & $1972: \mathrm{Q} 1-$ \\
& $2005: \mathrm{Q} 2$ & $2005: \mathrm{Q} 3$ & $2005: \mathrm{Q} 4$ & $2005: \mathrm{Q} 2$ & $2005: \mathrm{Q} 3$ & $1998: \mathrm{Q} 4$
\end{tabular}

NOTE: Standard errors are given in parentheses. If no standard error appears for a coefficient, this implies that the coefficient was set at a boundary value and not estimated. For the United States, the interest rate spread was used in place of the exchange rate.

where the densities are

(9)

$$
\begin{aligned}
& \ln L_{t}^{i, j, k}=-0.5 \ln \left(2 \pi \sigma^{2}\left(S 3_{t}=k\right)\right) \\
& -0.5 \exp \left(\hat{e}\left(S 1_{t}=i, S 2_{t}=j\right)_{t}^{2} / \sigma^{2}\left(S 3_{t}=k\right)\right) .
\end{aligned}
$$

\section{ESTIMATION RESULTS AND INTERPRETATION}

The central bank reaction function of equations (3) through (7) is used to find estimates for policy-implied baseline inflation rates for six countries: the United States, Australia, Canada, Germany, New Zealand, and the United Kingdom. Three countries that did not have formal inflation targets before 1994-the United States, Germany, and Australia-were included for purposes of comparison. The sample frequency is quarterly for all countries. The interest rate is a 3 -month rate, prices are measured by the consumer price index, and the exchange rate is the domestic/U.S. dollar rate except for the United Kingdom, where the pound/mark rate (pound/euro after 1999 in the updated data) is used. For the United States the exchange rate is replaced with an interest rate spread that represents the slope of the yield curve.

Table 1 presents the updated parameter estimates, with each country's date range at the bottom. (For Germany, the updated results run only through 1998:Q4, after which policymaking by the ECB began.) Parameter estimates without exchange rate feedback are in Table 2. For two of the three inflation targeters, the probability of being in the high-inflation regime when inflation targets were implemented was very low, as seen in Table 3. The exception is Canada, which experienced a period of elevated inflation at the same time the United States did (around 1990). Our principal focus is on the graphs of the regimeswitching baseline inflation rates, which are plotted alongside a one-year moving average of each country's inflation rate. Gaps between the actual inflation rate and the model-implied trend rate 
Table 2

Parameter Estimates without Exchange Rate Feedback

\begin{tabular}{lcccccc} 
Parameter & New Zealand & Australia & Canada & United States & United Kingdom & Germany \\
\hline$\pi_{0}(S 1=0)$ & $15.156(0.947)$ & $6.665(0.622)$ & $7.729(0.648)$ & $6.004(0.441)$ & $15.569(1.854)$ & $4.251(0.435)$ \\
$\pi_{0}(S 1=1)$ & $2.616(0.467)$ & $1.478(0.352)$ & $2.589(0.341)$ & $2.463(0.199)$ & $2.818(0.199)$ & $1.449(0.331)$ \\
$\sigma^{2}(S 3=0)$ & $7.639(3.738)$ & $3.203(0.644)$ & $3.737(1.098)$ & $8.125(2.419)$ & $2.148(0.379)$ & $3.051(0.901)$ \\
$\sigma^{2}(S 3=1)$ & $0.905(0.158)$ & $0.240(0.056)$ & $0.287(0.063)$ & $0.139(0.026)$ & $0.117(0.024)$ & $0.156(0.032)$ \\
$p_{1}$ & $0.968(0.043)$ & $0.990(0.013)$ & $0.830(0.095)$ & $0.872(0.072)$ & $0.987(0.012)$ & $0.934(0.051)$ \\
$q_{1}$ & $0.980(0.017)$ & $0.992(0.011)$ & $0.935(0.038)$ & $0.966(0.021)$ & 0.999 & $0.980(0.018)$ \\
$p_{3}$ & $0.919(0.060)$ & $0.956(0.027)$ & $0.942(0.039)$ & $0.846(0.089)$ & $0.922(0.061)$ & $0.946(0.045)$ \\
$q_{3}$ & $0.976(0.022)$ & $0.931(0.041)$ & $0.975(0.019)$ & $0.936(0.038)$ & $0.964(0.025)$ & $0.935(0.050)$ \\
Log-likelihood & -206.770 & -178.052 & -196.360 & -158.249 & -187.316 & -113.191 \\
Sample & $1975: Q 1-$ & $1976: Q 1-$ & $1970: Q 1-$ & $1972: Q 1-$ & $1972: Q 1-$ & $1972: Q 1-$ \\
& $2005: Q 2$ & $2005: Q 3$ & $2005: Q 4$ & $2005: Q 2$ & $2005: Q 3$ & $1998: Q 4$
\end{tabular}

NOTE: Standard errors are given in parentheses. If no standard error appears for a coefficient, this implies that the coefficient was set at a boundary value and not estimated.

\section{Table 3}

\section{Summary of Main Results}

\begin{tabular}{lcccc} 
& $\begin{array}{c}\text { Annual inflation when } \\
\mathbf{S 1} \text { = low state }\end{array}$ & $\begin{array}{c}\text { Pnnual inflation when } \\
\mathbf{S 1} \text { = high state }\end{array}$ & $\begin{array}{c}\text { Probability of being in } \\
\text { high-inflation state } \\
\text { when inflation targets } \\
\text { were announced }\end{array}$ & $\begin{array}{c}\text { Feedback } \\
\text { significant for } \\
\text { exchange rate }(\mathbf{S 2}=\mathbf{0})\end{array}$ \\
\hline United States & 2.22 & 5.20 & - & - \\
Australia & 1.39 & 6.63 & - & Yes \\
Germany & 1.70 & 4.79 & 0.90 & Yes \\
Canada & 2.59 & 7.73 & 0.01 & No \\
New Zealand & 2.99 & 15.65 & 0.21 & Yes \\
United Kingdom & 2.84 & 15.17 & No
\end{tabular}

can occur for two reasons: (i) a shock has caused actual inflation to deviate from its trend or (ii) inflation has moved to a new trend level so recently that the model's parameter estimates have not yet inferred the new trend level. It was especially important to distinguish between actual inflation and the model-implied trend rate in the early 1990s after an oil price shock in 1990.

In Figures 1 through $6,{ }^{9}$ panel $\mathrm{A}$ is based on the original estimates from D-F, panel B is based on updated estimates that allow for exchange rate feedback, and panel C is based on updated estimates that do not allow for exchange rate feedback.

\section{New Zealand versus Australia}

In 1991, the Reserve Bank of New Zealand adopted a pioneering inflation-targeting mandate, whereas the Reserve Bank of Australia had a more nebulous charge to keep inflation at levels

\footnotetext{
9 We thank Kluwer Academic Publishers for granting permission to reproduce Figures 1a through 6a from the original article in this updated version.
} 
comparable with those of its major trading partners. The Policy Targets Agreement between the Governor of the Reserve Bank of New Zealand and the Minister of Finance defined a precise target framework for inflation. A time frame, escape clauses, policy report, and sanctions within the Reserve Bank Act were clearly specified.

Based on Figures 1A and 2A, D-F concludes that, in a global environment of low inflation, it was difficult to say that formal inflation targets were instrumental in spurring disinflation in New Zealand and Australia, given that both countries experienced inflation regime shifts prior to adopting formal inflation targets. The indicator model suggests that New Zealand moved to a regime with a 4 percent inflation trend in about 1988, as seen in Figure 2A. Similarly, Figure 2A suggests that Australia shifted to a 3 percent inflation trend in 1992. With another decade of data, Figure 1B modifies the timing and magnitude of New Zealand's inflation regime shift to 1989 and a trend rate of about 3 percent. The updated inference for Australia in Figure 2B still identifies 1992 as the shift date but finds a trend rate of inflation of about 2 percent. Figures $2 \mathrm{C}$ and $3 \mathrm{C}$ do not alter the inferences regarding the timing and magnitude of the reductions in trend inflation, in the absence of exchange rate feedback. None of these updates runs counter to the interpretation that formal inflation targets served more as an ex post official stamp than a cause of disinflation.

\section{Canada versus the United States}

D-F note that, although the United States and Canada have undergone similar disinflationary cycles, Canadian inflation had usually remained above that of the United States between the collapse of the Bretton Woods system and 1992. After the Bank of Canada's announcement of explicit inflation targets in February 1991, however, Canadian inflation dipped below that of the United States for the first time since 1970 and remained low.

A key reason for the Bank of Canada to oppose an exchange rate peg was that U.S. monetary policy was viewed to be too growth oriented and the implicit inflation objective in the United States of 3 percent was regarded as too high. ${ }^{10}$ Hence, one intention of the announcement of a 1 to 3 percent inflation target by 1995 was to signal that the Bank of Canada had become serious about its objective of price stability. Indirectly, the Bank of Canada was also signaling that it wanted to do better than the United States in terms of inflation performance.

Figure 3A from D-F suggests that Canada's nascent policy regime was too new to allow the model to infer a trend inflation rate below 4 percent, although Figure 3A does show a widening gap between actual inflation and the modelimplied trend after 1992. The updated chart in Figure 3B, in contrast, highlights how much more stringently Canada has aimed at 3 percent inflation since 1992 than before. Figures 4A and 4B give a consistent picture of trend inflation in the United States: The trend rate went down to about 3 percent circa 1984 and has remained there, with the possible exception of a short period around 1990. Figures 3C and 4C show that neither exchange rate feedback (Canada) nor feedback from the term spread (United States) play an important role in shaping inferences regarding either country's disinflation. In sum, Canada's inflation targets appear to have helped match but not exceed the inflation performance of the United States, a country without formal inflation targets.

\section{United Kingdom versus Germany}

The actual and trend inflation paths for the United Kingdom and Germany, which are depicted in Figures 5A and 6A, show that British inflation, which has the higher historical average, has also been the more volatile. German inflation cycles tend to be more gradual. The different inflation records reflect the different targeting strategies of the two countries. The Bank of England pursued a policy of monetary targeting during the mid1970s to early 1980s. The Bank of England shifted its emphasis to the exchange rate prior to its entry into the European Monetary System in 1990, which it left in 1992. Since then it has followed a strategy of inflation targeting. As of 1994, the

\footnotetext{
${ }^{10}$ See Friedman (1995) for a discussion of inflation targeting in Canada.
} 
Figure 1

\section{Baseline Inflation Rate for New Zealand}

A. Original 1994 Estimates with Occasional Exchange Rate Feedback

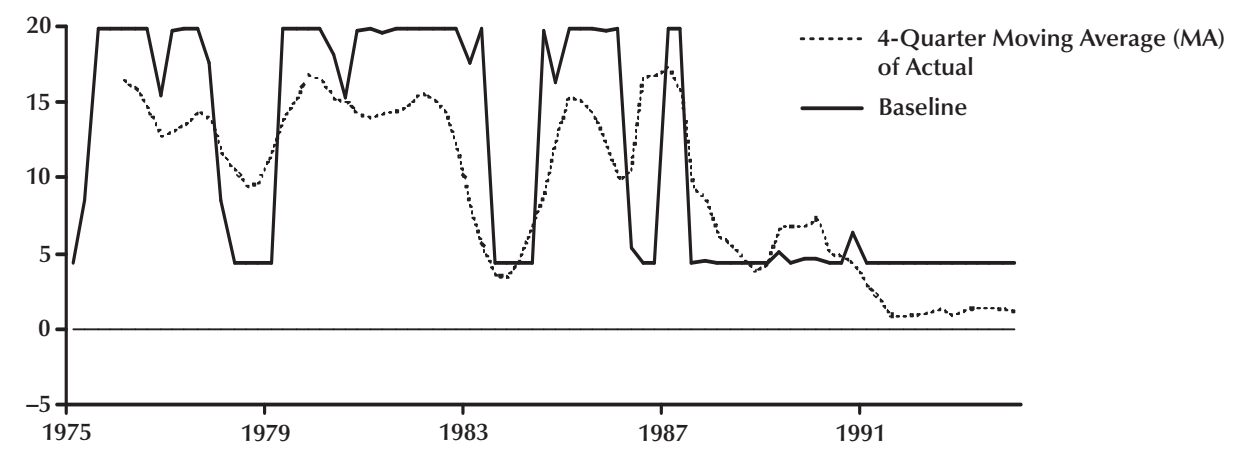

B. Updated Estimates with Occasional Exchange Rate Feedback

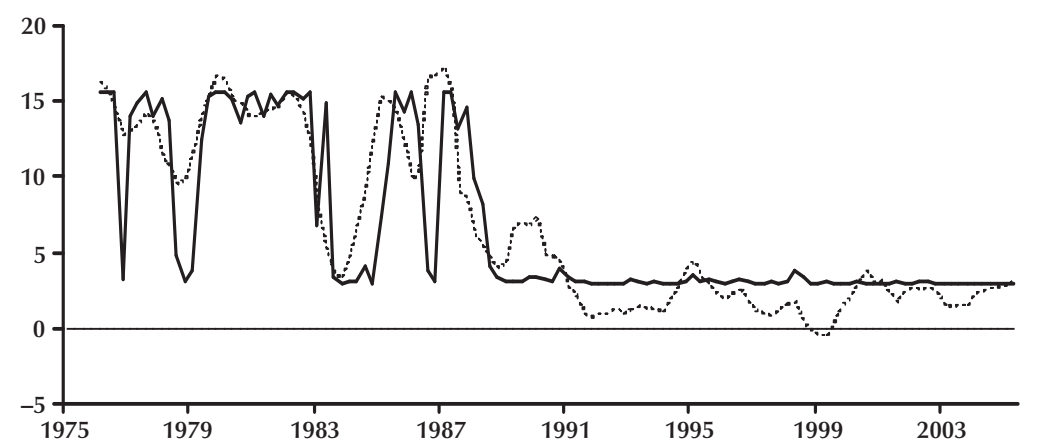

C. Updated Estimates without Exchange Rate Feedback

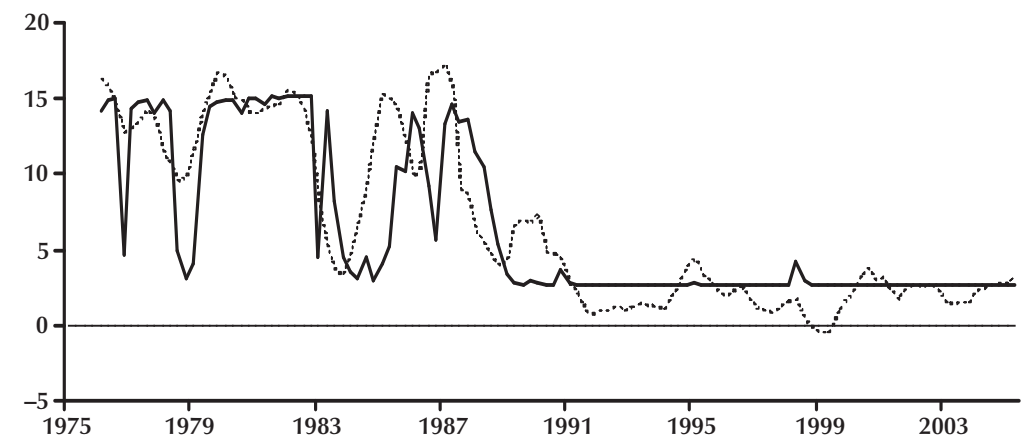




\section{Figure 2}

\section{Baseline Inflation Rate for Australia}

A. Original 1994 Estimates with Occasional Exchange Rate Feedback

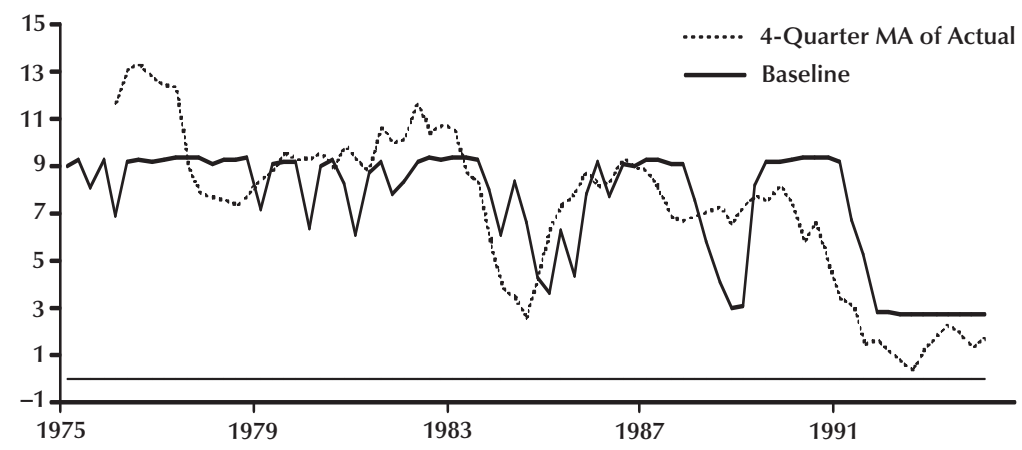

B. Updated Estimates with Occasional Exchange Rate Feedback

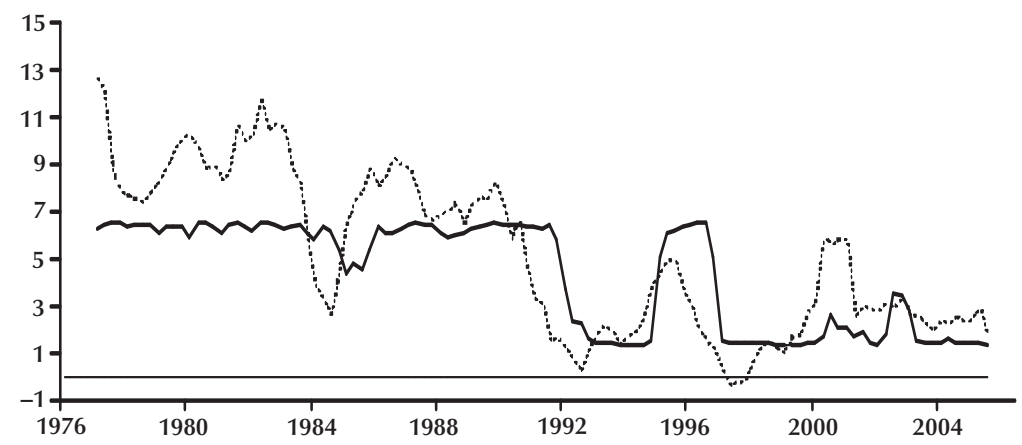

C. Updated Estimates without Exchange Rate Feedback

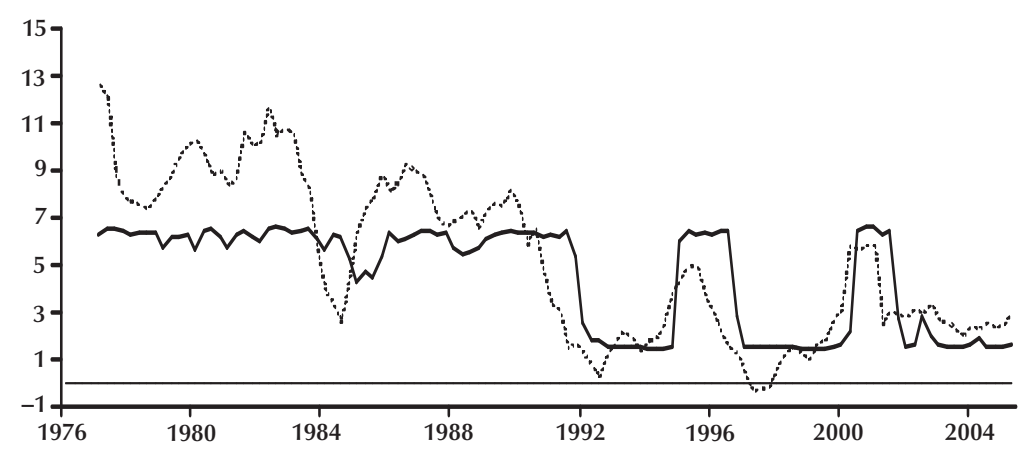


Figure 3

\section{Baseline Inflation Rate for Canada}

A. Original 1994 Estimates with Occasional Exchange Rate Feedback

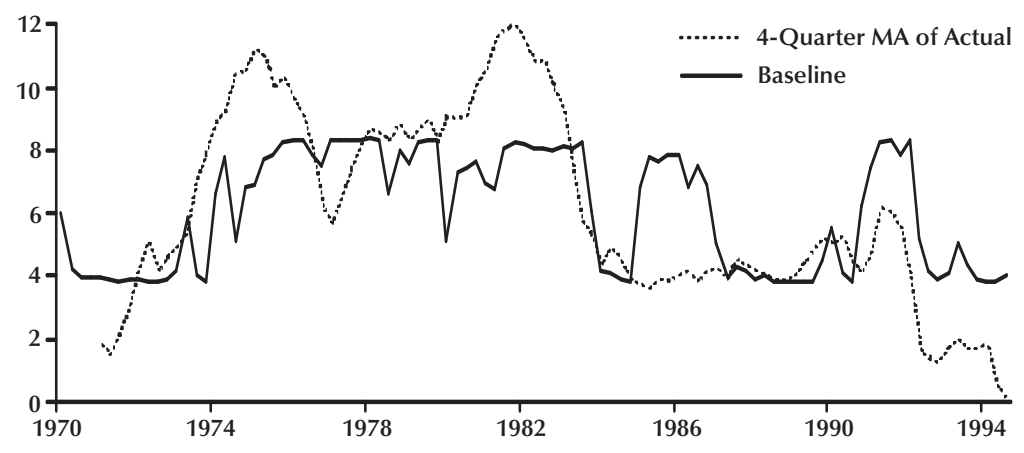

B. Updated Estimates with Occasional Exchange Rate Feedback

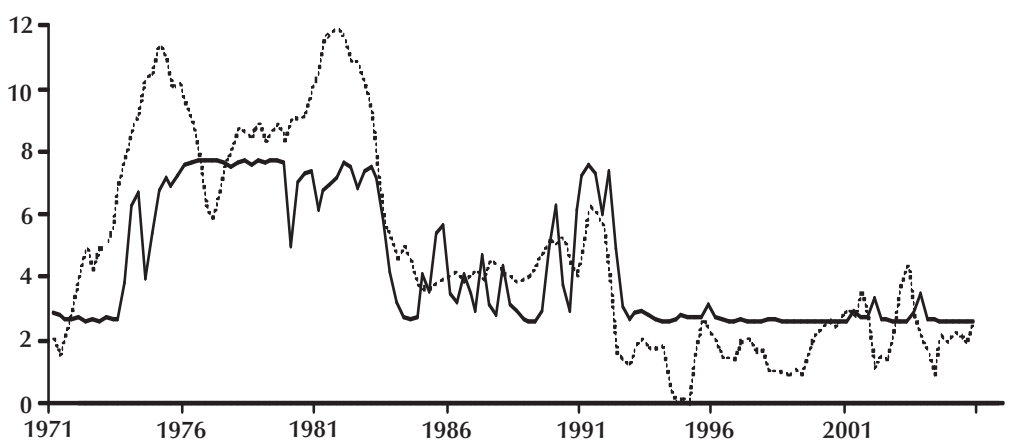

C. Updated Estimates without Exchange Rate Feedback

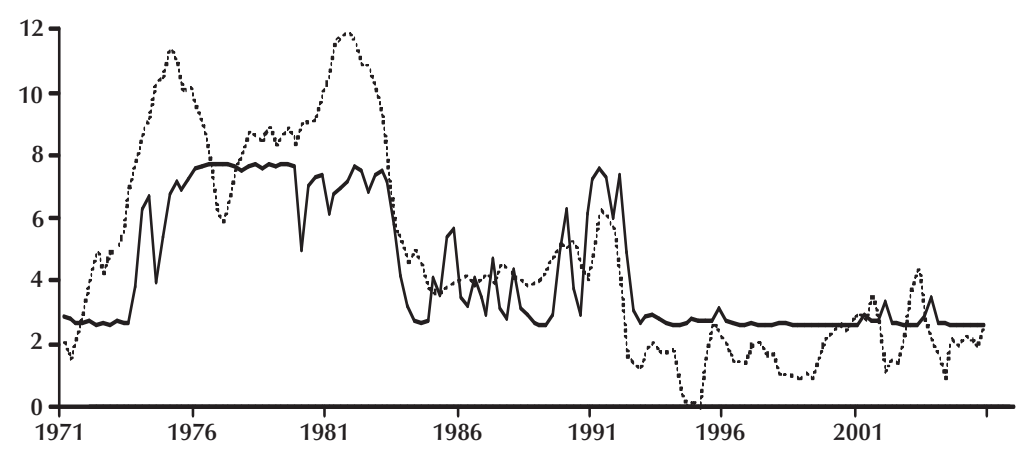




\section{Figure 4}

\section{Baseline Inflation Rate for the United States}

A. Original 1994 Estimates with Occasional Feedback from Term Spread

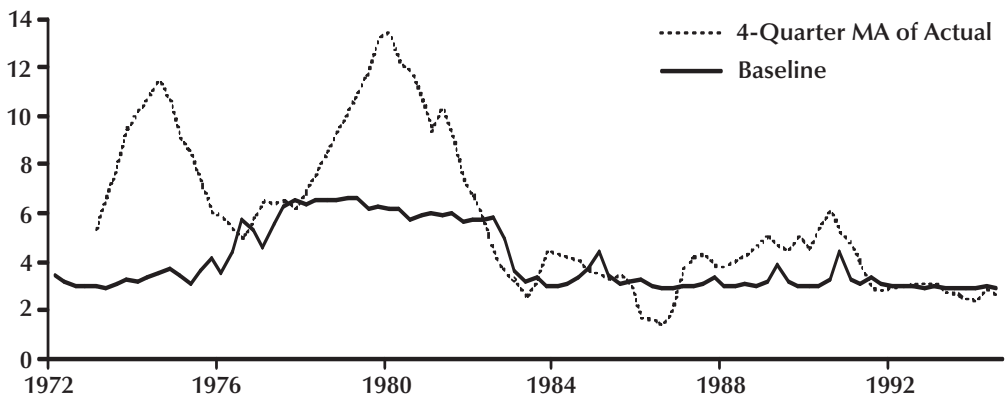

B. Updated Estimates with Occasional Feedback from Term Spread

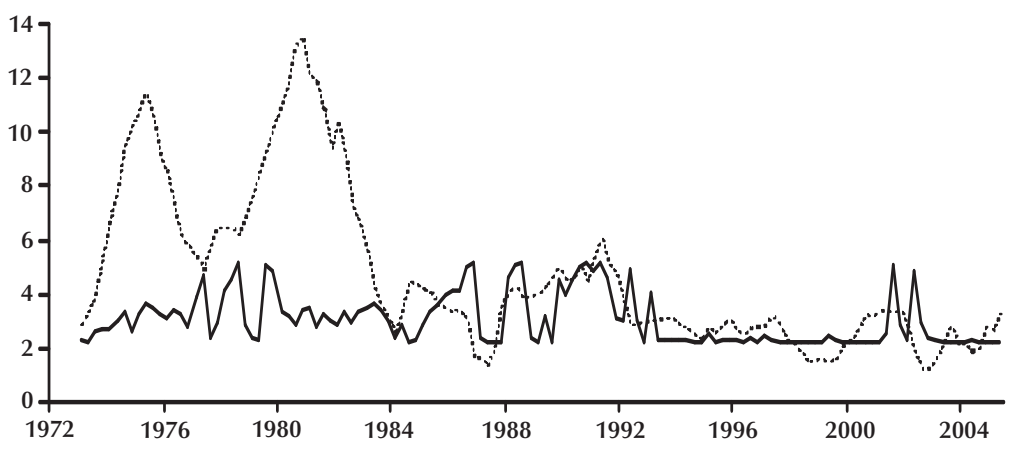

C. Updated Estimates without Feedback from Term Spread

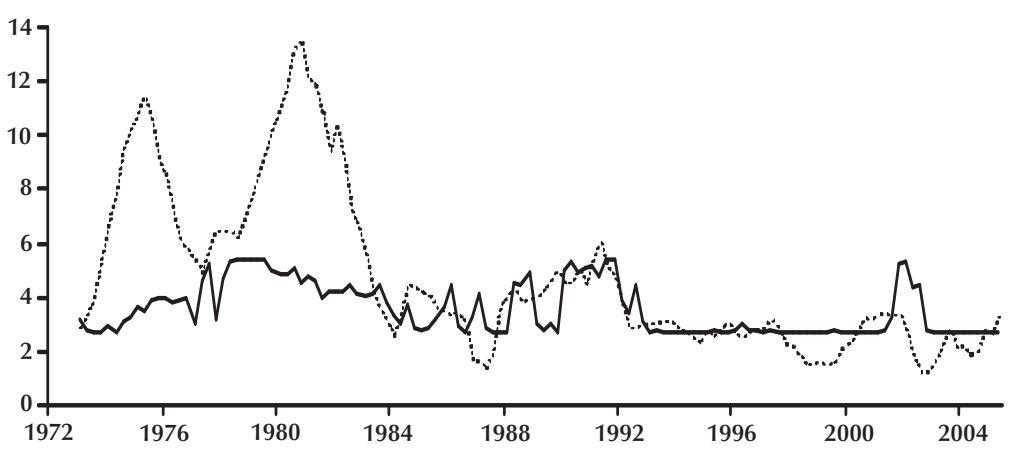


Figure 5

\section{Baseline Inflation Rate for the United Kingdom}

A. Original 1994 Estimates with Occasional Exchange Rate Feedback

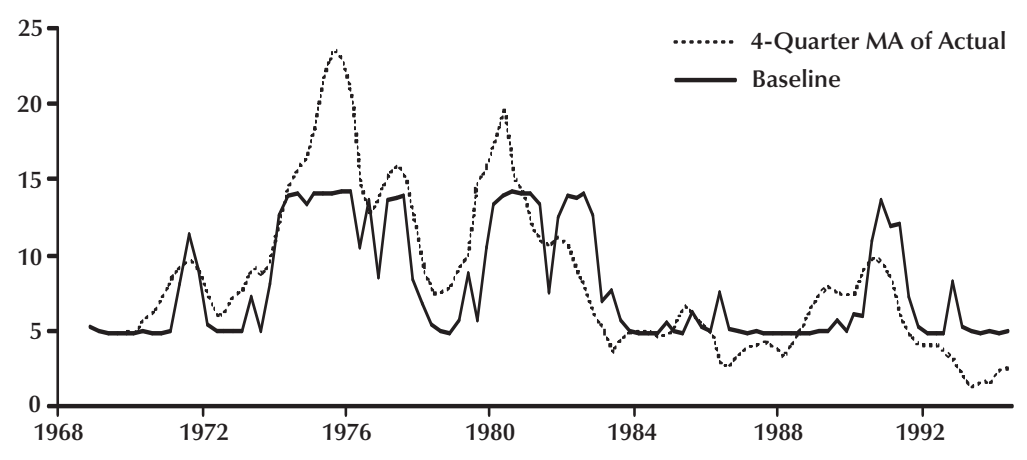

B. Updated Estimates with Occasional Exchange Rate Feedback

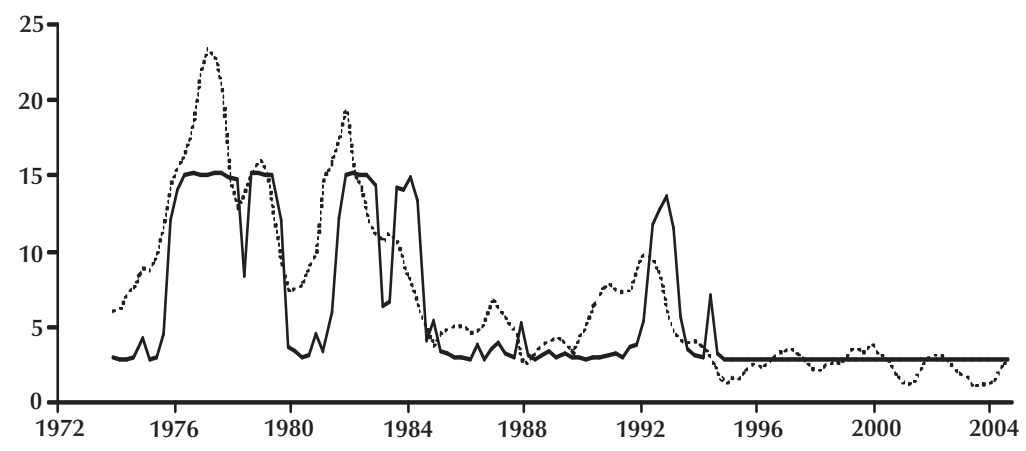

C. Updated Estimates without Exchange Rate Feedback

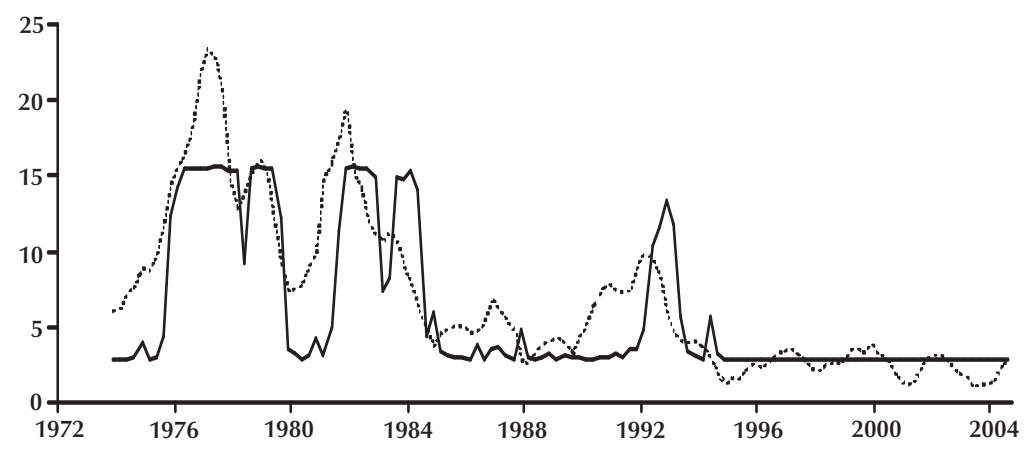




\section{Figure 6}

\section{Baseline Inflation Rate for Germany}

A. Original 1994 Estimates with Occasional Exchange Rate Feedback

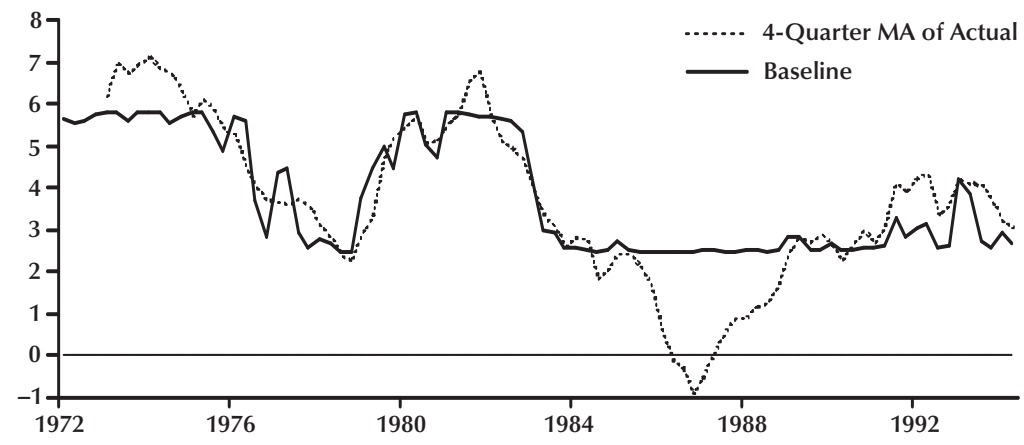

B. Updated (1998) Estimates with Occasional Exchange Rate Feedback

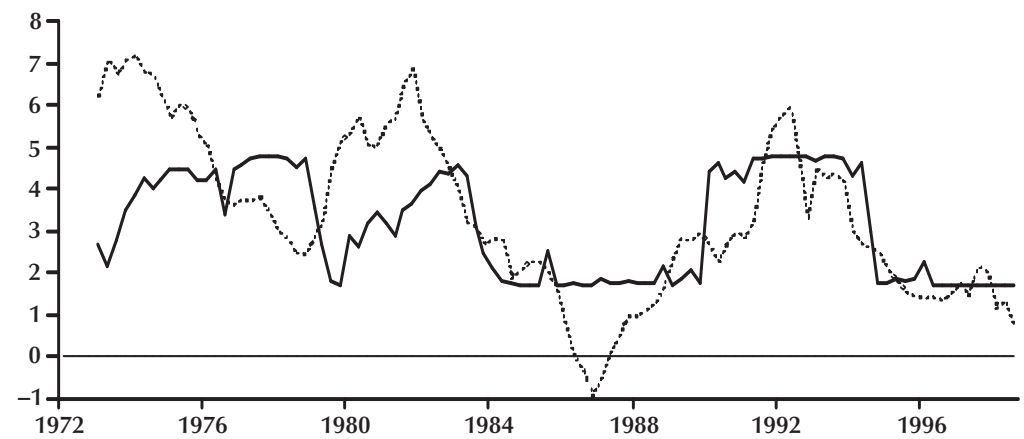

C. Updated (1998) Estimates without Exchange Rate Feedback

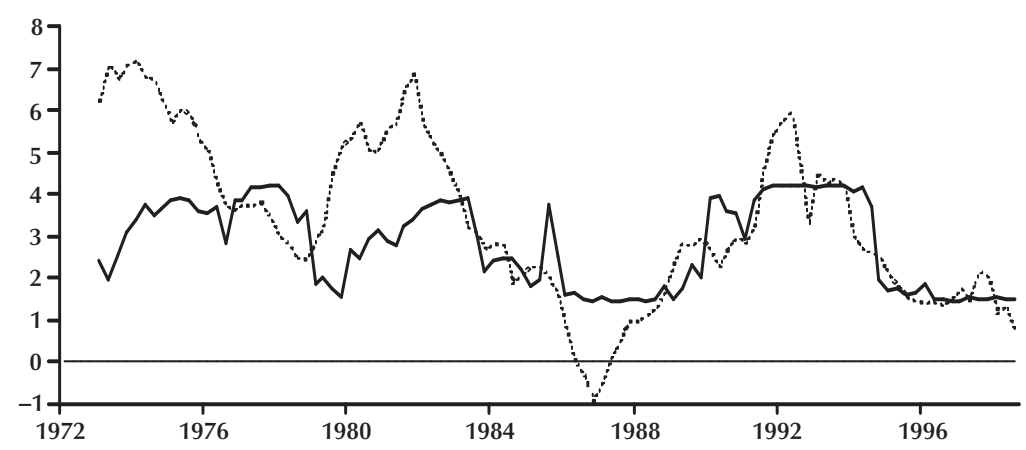




\section{Dueker and Fischer}

Bundesbank, in contrast, had maintained a nominal anchor in the form of monetary targets since 1975.

As with Canada, it was premature in 1994 to claim that the United Kingdom's trend rate of inflation appeared decisively lower than 5 percent after the introduction of inflation targets in late 1992, as shown in Figure 5A. With another decade of data, however, Figure 5B shows that the trend rate of inflation is estimated to have remained closer to 3 percent since 1992. Nevertheless this same trend rate also pertained to most of the 1980s.

Through 1994, D-F note that the estimates of the trend rate of inflation in Germany closely matched the Bundesbank's informal inflation targets, which were documented in von Hagen (2005). From 1975 to 1985, the Bank referred to the informal target as unavoidable inflation and this varied from year to year. From 1986 through 1998, the Bundesbank pursued a fixed, unconditional inflation target of 0 to 2 percent. D-F found in Figure 6A that the trend rate of inflation in Germany had remained at a level just below 3 percent from 1985 onward, even through the German reunification. With the additional data, Figure 6B suggests that Germany's baseline rate of inflation was about 1.5 percent after 1985, with the exception of the period around German reunification. Moreover, we know that the ECB has followed in the Bundesbank's footsteps in terms of keeping inflation at or below 2 percent in Europe. Thus, a decade later the United Kingdom can still be viewed as a follower in terms of carving a path of low inflation in Europe. Figures 5C and $6 \mathrm{C}$ do not contradict this conclusion, either, when the effects of any exchange rate feedback are removed.

\section{CONCLUSION}

Dueker and Fischer (1996a) provided the first comparative empirical analysis between a set of inflation-targeting countries and neighboring countries without formal inflation targets. Both the original study and the updated estimates presented here suggest that inflation-targeting countries generally followed a non-inflationtargeting neighbor in reducing their baseline or trend inflation rates. We also survey numerous empirical studies of inflation-targeting countries from the past decade and find very similar conclusions. Thus, on the heels of a decade of low global inflation, it has been hard to argue that formal inflation targets have led to any divergence between targeters and non-targeters in terms of inflation performance.

\section{REFERENCES}

Alders, Koos; Koedijk, Kees; Kool, Clemens and Winder, Carlo. "Monetary Policy in a Converging Europe: Overview of the Issues and Summary of the Discussion,” in Koos Alders, Kees Koedijk, Clemens Kool, and Carlo Winder, eds., Monetary Policy in a Converging Europe. Dordrecht, Netherlands: Kluwer, 1996, pp. 1-19.

Almeida, Alvaro and Goodhart, Charles A.E. "Does the Adoption of Inflation Targets Affect Central Bank Behaviour?" Banca Nazionale del Lavoro Quarterly Review, March 1998, 51(4), pp. 19-107.

Ball, Laurence and Sheridan, Niamh. "Does Inflation Targeting Matter,” in Ben S. Bernanke and Michael Woodford, eds., The Inflation-Targeting Debate. Chicago: University of Chicago, 2004, pp. 249-76.

Batini, Nicoletta and Laxton, Douglas. "Under What Conditions Can Inflation Targeting Be Adopted? The Experience of Emerging Markets." Unpublished manuscript, 2005; www.bcentral.cl/esp/estpub/ conferencias/anuales/pdf/2005/Batini.pdf.

Bernanke, Ben S.; Laubach, Thomas; Mishkin, Frederic S. and Posen, Adam S. Inflation Targeting. Princeton: Princeton University, 1999.

Bowen, Alex. "British Experience with Inflation Targetry," in Leonardo Leiderman and Lars E.O. Svensson, eds., Inflation Targets. London: Centre for Economic Policy Research, 1995, pp. 53-68.

Cecchetti, Stephen and Ehrmann, Michael. "Does Inflation Targeting Increase Output Volatility? An International Comparison of Policymakers Preferences and Outcomes," in Norman Loayza and Klaus Schmidt-Hebbel, eds., Monetary Policy: 
Rules and Transmission Mechanisms. Santiago: Central Bank of Chile, 2002, pp. 247-74.

Corbo, Vittorio; Landerretche, Oscar and SchmidtHebbel, Klaus. "Does Inflation Targeting Make a Difference?" in Inflation Targeting: Design, Performance, Challenges. Series on Central Banking, Analysis, and Economic Policies. Volume 5. Santiago: Bank of Chile, 2002, pp. 221-69.

Dueker, Michael J. and Fischer, Andreas M. "Do Inflation Targets Redefine Central Bank Inflation Preferences? Results from an Indicator Model," in Koos Alders, Kees Koedijk, Clemens Kool, and Carlo Winder, eds., Monetary Policy in a Converging Europe. Dordrecht, Netherlands: Kluwer, 1996a, pp. 21-37.

Dueker, Michael J. and Fischer, Andreas M. "Inflation Targeting in a Small Open Economy: Empirical Results for Switzerland." Journal of Monetary Economics, February 1996b, 37(1), pp. 89-103.

Dueker, Michael J. and Fischer, Andreas M. “A Guide to Nominal Feedback Rules and Their Use for Monetary Policy." Federal Reserve Bank of St. Louis Review, July/August 1998, 80(4), pp. 55-63.

Dueker, Michael J. and Fischer, Andreas M. "The Mechanics of a Successful Exchange Rate Peg: Lessons for Emerging Markets.” Federal Reserve Bank of St. Louis Review, September/October 2001, 83(5), pp. 47-56.

Fischer, Andreas M. "New Zealand's Experience with Inflation Targets," in Leonardo Leiderman and Lars E.O. Svensson, eds., Inflation Targets. London: Centre for Economic Policy Research, 1995, pp. 32-52.

Fraga, Arminio; Goldfajn, Iian and Minella, André. "Inflation Targeting in Emerging Market Economies," in Mark Gertler and Kenneth Rogoff, eds., NBER Macroeconomics Annual 2003. Cambridge, MA: MIT Press, 2004, pp. 365-99.

Freedman, Charles. "The Canadian Experience with Targets for Reducing and Controlling Inflation," in Leonardo Leiderman and Lars E.O. Svensson, eds., Inflation Targets. London: Centre for Economic Policy Research, 1995.
Gertler, Mark. "Comment," in Ben S. Bernanke and Michael Woodford, eds., The Inflation-Targeting Debate. Chicago: University of Chicago, 2005, pp. 276-81.

Groenevald, Hans M.; Koedijk, Kees G. and Kool, Clemens J.M. "Inflation Dynamics and Monetary Strategies: Evidence from Six Industrialized Countries." Open Economies Review, January 1998, 9(1), pp. 21-38.

Hamilton, James. "Rational Expectations Econometric Analysis of Changes in Regimes: An Investigation of the Term Structure of Interest Rates." Journal of Economic Dynamics and Control, June/September 1988, 12(2/3), pp. 385-432.

Hyvonen, Markus. "Inflation Convergence Across Countries.” Working Paper No. 2004-04, Reserve Bank of Australia, June 2004.

International Monetary Fund. IMF World Economic Outlook. Chapter 4. Washington, DC: International Monetary Fund, 2005.

Johnson, David R. "The Effect of Inflation Targets on the Level of Expected Inflation in Five Countries." Review of Economics and Statistics, November 2003, 85(4), pp. 1076-81.

Johnson, David R. “The Effect of Inflation Targeting on the Behavior of Expected Inflation: Evidence from an 11 Country Panel." Journal of Monetary Economics, November 2002, 49(8), pp. 1521-38.

Jonas, Jiri and Mishkin, Frederic S. "Inflation Targeting in Transition Economies: Experience and Prospects," in Ben S. Bernanke and Michael Woodford, eds., The Inflation-Targeting Debate. Chicago: University of Chicago, 2005, pp. 353-413.

Laidler, David E.W. and Robson, William B.P. The Great Disinflation: The Economics and Politics of Monetary Policy in Canada 1988-1993. Toronto: C.D. Howe Institute, 1993.

Lee, Jim. "Inflation Targeting in Practice: Further Evidence." Contemporary Economic Policy, July 1999, 17(3), pp. 332-47. 


\section{Dueker and Fischer}

Leiderman, Leonardo and Svensson, Lars E.O., eds. Inflation Targets. London: Centre for Economic Policy Research, 1995.

Levin, Andrew T.; Natalucci, Fabio M. and Piger, Jeremy M. "The Macroeconomic Effects of Inflation Targeting." Federal Reserve Bank of St. Louis Review, July/August 2004, 86(4), pp. 51-80.

McCallum, Bennett T. "The Case for Rules in the Conduct of Monetary Policy: A Concrete Example." Federal Reserve Bank of Richmond Economic Review, September/October 1987, 73(5), pp. 10-18.

McCallum, Bennett T. "Specification and Analysis of a Monetary Policy Rule for Japan." Monetary and Economic Studies, November 1993, 11(2), pp. 1-45.

McCallum, Bennett T. "Inflation Targeting in Canada, New Zealand, Sweden, the United Kingdom, and in General.” NBER Working Paper No. 5579, National Bureau of Economic Research, 1998.

Mishkin, Frederic S. "Commentary.” Federal Reserve Bank of St. Louis Review, July/August 2002, 84(4), pp. 149-54.

Mishkin, Frederic S. "Comments," in Mark Gertler and Kenneth Rogoff, eds., NBER Macroeconomics Annual 2003. Cambridge, MA: MIT Press, 2004, pp. 403-08.

Nadal-De Simone, Francisco. "Inflation Targeters in Practice: A Lucky Lot?” Contemporary Economic Policy, July 2001, 19(3), pp. 239-53.

Neumann, Manfred and von Hagen, Jürgen. "Does Inflation Targeting Matter?" Federal Reserve Bank of St. Louis Review, July/August 2002, 84(4), pp. 127-48.

Pétursson, Thórarinn G. "The Effects of Inflation Targeting on Macroeconomic Performance." Working Paper No. 23, Central Bank of Iceland, 2004.

Rasche, Robert H. and Williams, Marcela M. "The Effectiveness of Monetary Policy." Working Paper No. 2005-048B, Federal Reserve Bank of St. Louis, 2005.
Siklos, Pierre L. "Inflation Target Design: Changing Performance and Persistence in Industrial Countries.” Federal Reserve Bank of St. Louis Review, March/April 1999, 81(2), pp. 47-58.

Stevens, Glenn. "Pitfalls in the Use of Monetary Conditions Indexes." Presented to the Australian Business Economists, July 16, 1998; www.rba.gov.au/Speeches/1998/sp_ag_160798.html.

Svensson, Lars E.O. "The Swedish Experience of an Inflation Target," in Leonardo Leiderman and Lars E.O. Svensson, eds., Inflation Targets. London: Centre for Economic Policy Research, 1995, pp. 69-89.

Svensson, Lars and Woodford, Michael.

"Implementing Optimal Policy through InflationForecast Targeting." CEPR Discussion Paper No. 4229, Centre for Economic Policy Research, 2004.

Taylor, John B. "Discretion versus Policy Rules in Practice." Carnegie-Rochester Conference Series on Public Policy, 1993, 39, pp. 195-214.

Uhlig, Harald. "Commentary.” Federal Reserve Bank of St. Louis Review, July/August 2004, 86(4), pp. 81-88.

Vega, Marco and Winkelried, Diego. "Inflation Targeting and Inflation Behavior: A Successful Story?” International Journal of Central Banking, December 2005, 1(3), pp. 153-75.

von Hagen, Jürgen. "Inflation and Monetary Targeting on Germany," in Leonardo Leiderman and Lars E.O. Svensson, eds., Inflation Targets. London: Centre for Economic Policy Research, 2005, pp. 107-21.

Woodford, Michael. "Inflation Targeting and Optimal Monetary Policy." Federal Reserve Bank of St. Louis Review, July/August 2004, 86(4), pp. 15-41.

Zurlinden, Mathias. "The Vulnerability of Pegged Exchange Rates: The British Pound in the ERM." Federal Reserve Bank of St. Louis Review, September/October 1993, 75(5), pp. 41-56. 